\title{
Sequences of the envM gene and of two mutated alleles in Escherichia coli
}

\author{
Helmut Bergler, Gregor Högenauer and Friederike TurnowsKy* \\ Institut für Mikrobiologie, Karl-Franzens-Universität Graz, Universitätsplatz 2, A-8010 Graz, Austria
}

(Received 24 April 1992; revised 25 June 1992; accepted 30 June 1992)

\begin{abstract}
The nucleotide sequence of the Escherichia coli envM gene was determined. It codes for a protein of 262 amino acids. The sequences of the $E$. coli and Salmonella typhimurium EnvM proteins are $98 \%$ identical. Gene envM is preceded in $E$. coli by a 43-nucleotide-long structural element, termed 'box C', which occurs in several $E$. coli operons between structural genes. This sequence element is totally absent in $S$. typhimurium. Gene envM was mapped at coordinate position $1366.8 \mathrm{~kb}$ of the physical map of Kohara et al. (Cell, 1987, 50, 495-508). As in $S$. typhimurium, a Gly for Ser exchange at position 93 of the amino acid sequence leads to a diazaborine-resistant $E$. coli phenotype. A Ser for Phe exchange at position 241 of the EnvM protein results in a temperature-sensitive growth phenotype. Comparison of the EnvM amino acid sequence with sequences available in databases showed significant homology with the family of short-chain alcohol dehydrogenases.
\end{abstract}

\section{Introduction}

The envM gene from Salmonella typhimurium has previously been cloned and sequenced (Turnowsky et al., 1989). The gene product is essential for growth as it plays an important role in the biosynthesis of phospholipids and lipopolysaccharides by Enterobacteriaceae (Högenauer \& Woisetschläger, 1981). The protein is the target of a group of antibacterial drugs, the diazaborines, the important structural element of which is a heterocyclic 1,2-diazine ring containing boron as a third hetero atom (Grassberger et al., 1984).

One allelic form of $e n v M$ with a temperature-sensitive (ts) growth phenotype in $E$. coli was described by Egan \& Russell (1973). The effects on lipid biosynthesis and on cell morphology in this mutant at the nonpermissive temperature were comparable to those caused by drug treatment. The ts-phenotype in $E$. coli could be complemented by introducing the corresponding wild-type (wt) gene from $S$. typhimurium (Turnowsky et al., 1989). Furthermore, wild-type $E$. coli cells became diazaborineresistant after transformation with a plasmid carrying the resistant allelic form of the gene isolated from a drugresistant $S$. typhimurium mutant.

We have cloned and sequenced the corresponding $E$.

* Author for correspondence. Tel. 316380 5620; fax 316381548.

The nucleotide sequence data reported in this paper have been submitted to GenBank and have been assigned the accession number M97219. coli wild-type gene from a recombinant phage of the collection described by Kohara et al. (1987), which represents the entire $E$. coli chromosome. The correct recombinant phage was chosen on the basis of $\mathrm{Pl}$ transduction experiments, which allowed the precise localization of the gene at min 28.5 (Turnowsky et al., 1989).

When we analysed sequences isolated from either a drug-resistant $E$. coli mutant or from the $E$. coli ts-mutant of Egan \& Russell (1973), we identified in each case single nucleotide exchanges which result in altered amino acid sequences. These analyses are described in the present communication.

\section{Methods}

Bacterial strains, phages and plasmids. Strains, phage and plasmids are listed in Table 1. E. coli cells were grown in either LB-medium (Miller, 1972) or $2 \times$ YT medium (Sambrook et al., 1989), unless otherwise stated. Dia $^{\mathrm{R}}$ designates diazaborine resistance. Antibiotics were added when needed at the following concentrations: diazaborine $20 \mu \mathrm{g} \mathrm{ml}^{-1}$, epicillin $100 \mu \mathrm{g} \mathrm{ml}^{-1}$.

Chemicals and enzymes. Epicillin was from Biochemie (Kundl, Austria). Radiochemicals were obtained from Amersham or from Dupont-NEN. Enzymes for DNA work were from Boehringer, BRL or New England Biolabs. For oligonucleotide synthesis, the reagents were from Applied Biosystems.

DNA work. Recombinant techniques were performed by the methods of Ausubel et al. (1987), Sambrook et al. (1989), or by following the protocols of the manufacturers. DNA from the recombinant phage 18B6 (Kohara et al., 1987) was isolated according to Silhavy et al. (1984). Single-stranded DNA was prepared from recombinant 
Table 1. Bacterial strains, phage, and plasmids

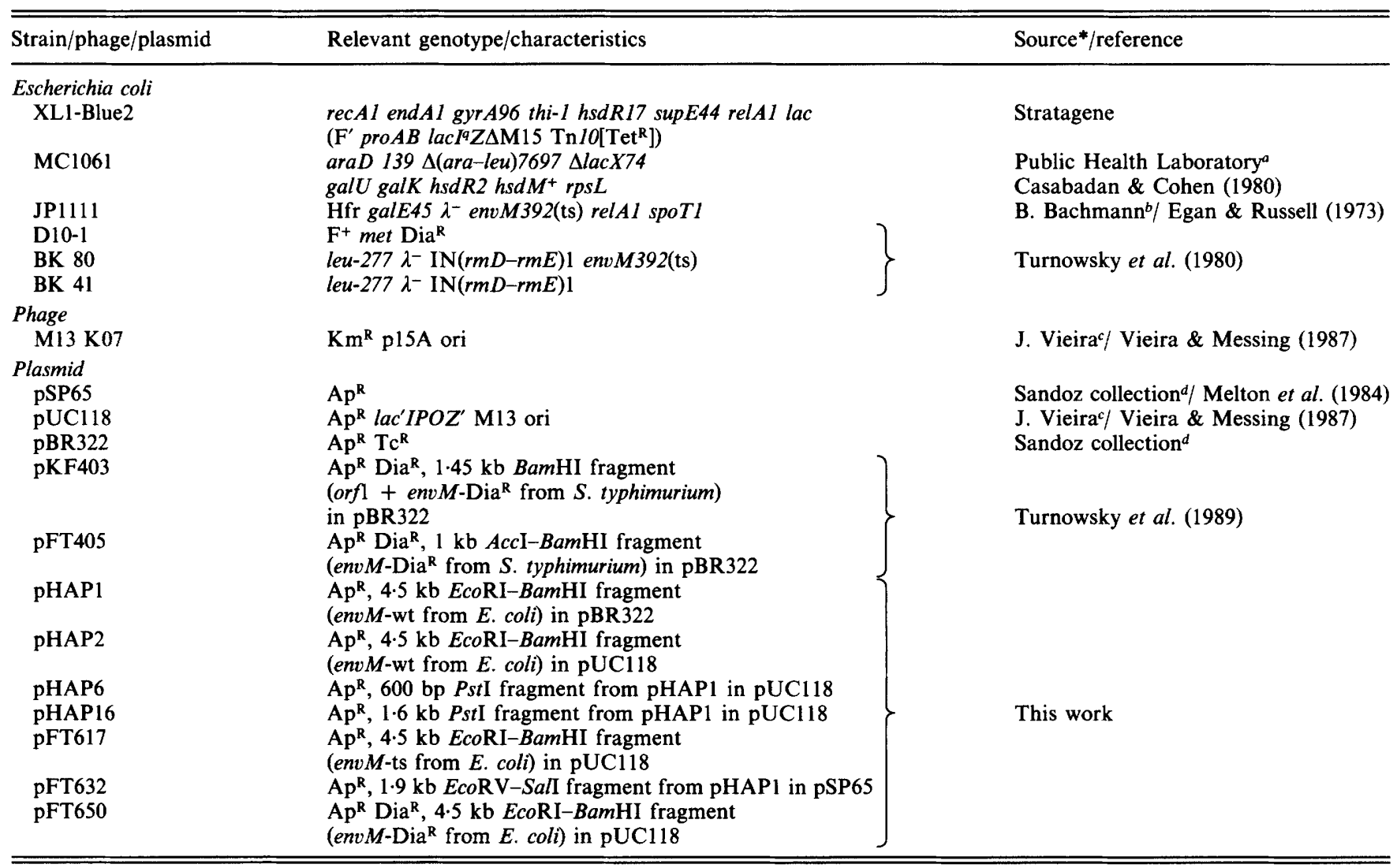

* Addresses: $a$, Public Health Laboratory, Porton Down, UK ; $b$, B. Bachmann, E. coli Genetic Stock Center, New Haven, CT, USA; $c$, J. Vieira, Waksman Institute of Microbiology, Piscataway, NJ, USA; $d$, Sandoz collection, Sandoz Forschungsinstitut, Vienna, Austria.

plasmids derived from pUC118 using the helper phage M13K07 (Vieira \& Messing, 1987).

Cloning procedures. The general strategies for cloning the wt, the $\mathrm{Dia}^{\mathrm{R}}$ and the ts alleles of the envM gene are described in Results. Labelled DNA probes for Southern hybridization and colony hybridization experiments were prepared either by nick-translation of the BamHI fragment of pKF403 (Turnowsky et al., 1989), or by random priming using the $1.6 \mathrm{~kb}$ Pst I fragment of pHAP1 or the $1 \mathrm{~kb}$ BamHIAccI fragment of pFT405 (Turnowsky et al., 1989) as templates. The recombinant plasmids carrying the wt, the $\mathrm{Dia}^{\mathrm{R}}$ and the ts alleles of envM were designated pHAP1, pFT650 and pFT617, respectively. Transformations were done by the standard $\mathrm{CaCl}_{2}$ protocol.

DNA sequencing. The sequences of the DNA fragments containing the allelic forms of the envM gene were determined in the singlestranded form by the chain-termination method of Sanger et al. (1977), with both universal and specific oligonucleotide primers, using a Sequenase kit (United States Biochemicals).

Growth curves and complementation of the ts-phenotype. The isogenic strains $E$. coli BK80 and E. coli BK41 (Turnowsky et al., 1989) were transformed with the recombinant plasmids pHAP2 and pFT617, as well as with the vector pUC118. The transformants were grown in Trypticase Soy Broth (Merck) at $30^{\circ} \mathrm{C}$ to early exponential phase; the cultures were then shifted to $42^{\circ} \mathrm{C}$ and the incubation continued for $4.5 \mathrm{~h}$. The optical density at $600 \mathrm{~nm}$ was measured at various time points after the temperature shift. In separate experiments, E. coli
JP1111 was transformed with subclones of pHAP2, namely pFT632, pHAP6 and pHAP16 (Fig. 1), and the transformants tested for growth in $\mathrm{LB}$ medium at $42^{\circ} \mathrm{C}$ in overnight cultures.

Computer-assisted sequence analysis. The GCG software package of the Wisconsin computer group (Devereux et al., 1984) was used for all sequence analyses. Sequence databases (EMBL, GenBank and Swiss Prot) were screened using the 'wordsearch' program. Multiple sequence alignment was done with the program 'pile up'.

\section{Results and Discussion}

\section{Cloning the E. coli wild-type envM gene}

The recombinant phage $18 \mathrm{~B} 6$ from the collection described by Kohara et al. (1987) carries the region around min 28.5 of the $E$. coli chromosome. Based on previous work (Turnowsky et al., 1989), this region was expected to contain the envM gene. DNA from the phage was prepared and cleaved with various restriction endonucleases, either alone or in combination. The fragments obtained were separated by agarose gel electrophoresis and analysed by Southern blotting. As a 


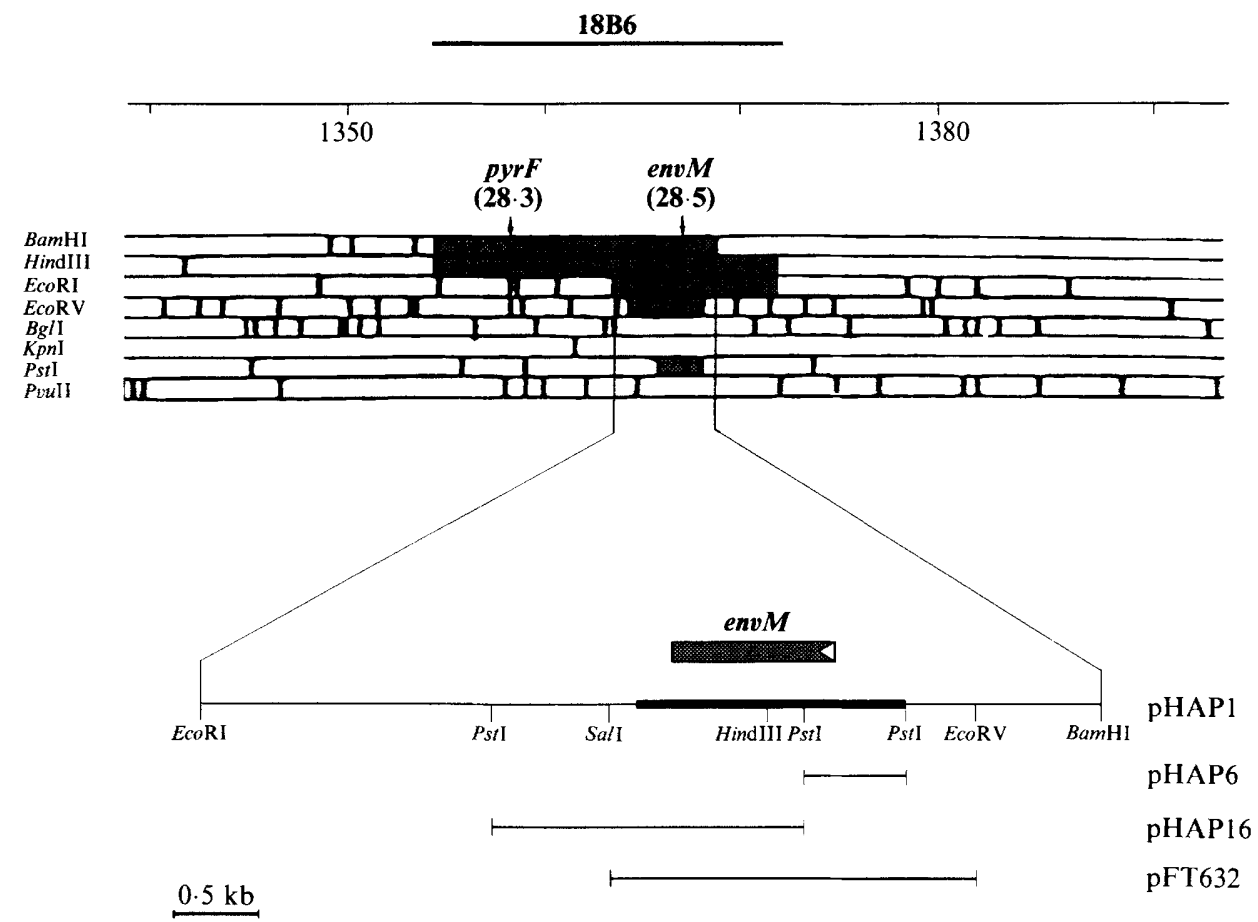

Fig. 1. Section of the physical map from 1340 to $1390 \mathrm{~kb}$ of the $E$. coli chromosome as described by Kohara et al. (1987). The locations of the $e n v M$ and the $p y r F$ genes are indicated : they map at $\min 28.5$ and $\min 28 \cdot 3$, respectively. $18 \mathrm{~B} 6$ designates the recombinant phage carrying the investigated region of the $E$. coli chromosome. The DNA restriction fragments that hybridized with a probe containing the envM gene from $S$. typhimurium are shown as hatched areas. The restriction enzymes $B g l$, $K p n I$ and $P v u I I$ were not tested. Below, the restriction map of the $4.5 \mathrm{~kb} E c o \mathrm{RI}-\mathrm{BamHI}$ fragment in pHAP1 is shown. The sequenced region is marked as a thick line. The location of envM in the insert is shown as a hatched bar above the restriction map with the orientation of transcription indicated as an arrowhead. Underneath, the inserts of relevant subclones, i.e. pHAP6, pHAP16 and pFT632, are shown.

probe, a DNA fragment from $S$. typhimurium (pKF403) containing the entire $e n v M$ gene was used. The fragments which gave signals after autoradiography are shown in Fig. 1 as hatched areas. The $4.5 \mathrm{~kb}$ EcoRIBamHI fragment was isolated and partially sequenced. The recombinant plasmid was designated pHAP1.

Complementation assays showed that we had indeed cloned the envM gene: when pHAP1 was introduced into $E$. coli JP1111, the envM-ts mutant, temperatureinsensitive growth was observed. The smallest subclone tested that was able to complement was pFT632, containing the $1.9 \mathrm{~kb} E c o \mathrm{RV}-S a l$ fragment. The recombinant plasmids pHAP6 and pHAP16, which carry the two Pst I fragments and which are shown shaded in Fig. 1 , did not complement. Hence, the env $M$ gene contains a single PstI site. On the basis of these mapping experiments we assign the location of gene envM to coordinates $1366.8 \mathrm{~kb}$ of the Kohara et al. (1987) map.

\section{Nucleotide sequence}

Part of the BamHI-EcoRI fragment was sequenced by the dideoxy method of Sanger et al. (1977) using the vector plasmid pUC118. Both strands of appropriate subclones were independently sequenced in the singlestranded form using universal and specific oligonucleotide primers. Fig. 2 shows the sequence, covering $1366 \mathrm{nt}$ (nucleotides) from the PstI site towards the EcoRI site of the original fragment. This sequence was searched for open reading frames (ORFs) by applying the 'positional base preference' and the 'testcode' methods using the SASP-software of the Genetic Computer Group, University of Wisconsin (Devereux et al., 1984). One complete reading frame was found, from nt 404 through nt 1190 , which showed an identity with the corresponding gene from $S$. typhimurium of $85 \%$ at the nucleotide level and $98 \%$ at the amino acid level, respectively. Thus, this ORF is the envM gene of $E$. coli. It codes for a protein of 262 amino acids with a calculated molecular mass of $27868 \mathrm{Da}$. Only six amino acids differ from the wild-type $S$. typhimurium gene product. The sequence of the first 30 $\mathrm{N}$-terminal amino acids of the EnvM protein was determined by Edman degradation. It was identical with that derived from the DNA sequence (not shown).

Although the envM genes of $S$. typhimurium and E. coli show a very high degree of homology, the flanking DNA 


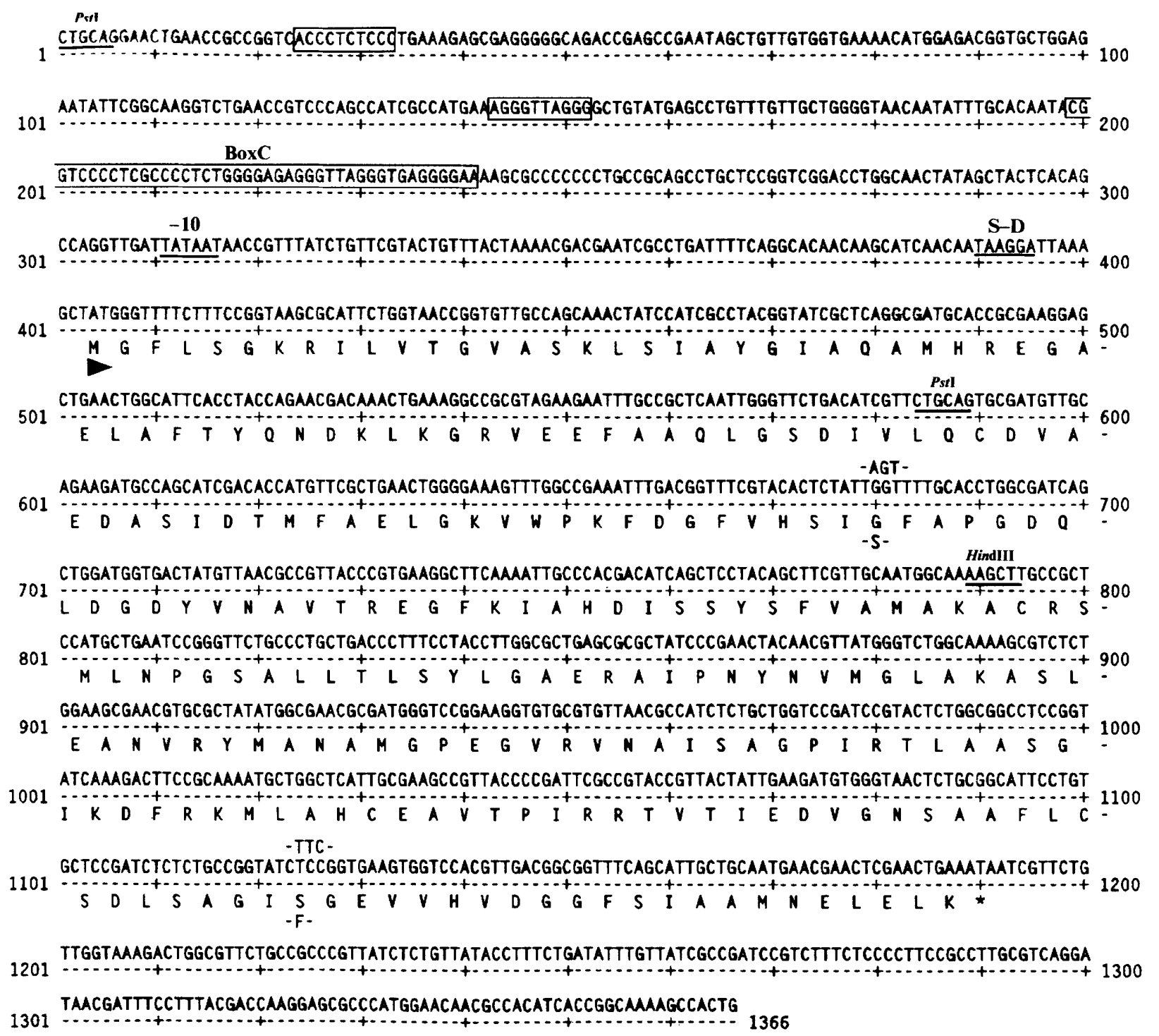

\begin{abstract}
Fig. 2. Partial nucleotide sequence of pHAP1, starting at the PstI site upstream of envM towards the EcoRI site of the original fragment, containing the complete wt-envM gene. Relevant restriction sites are indicated. A possible promoter sequence is underlined and marked -10 . The putative ribosome binding site is also underlined and termed S-D. envM starts at nt 404 and ends at nt 1190 ; the direction of translation is indicated by an arrowhead below the sequence. The mutations in position 680 leading to the resistancephenotype and in position 1125 leading to the ts-phenotype are indicated as altered codons above the sequence. The altered amino acids, a serine and a phenylalanine, respectively, are shown below the sequence. The deduced amino acid sequence is shown in the one-letter code. The highly conserved region 'box C', and partial sequences thereof in both orientations are boxed.
\end{abstract}

proved to be entirely different. In $S$. typhimurium, gene env $M$ is preceded by a short ORF (orf1; Turnowsky et al., 1989) coding for a polypeptide of $10445 \mathrm{Da}$. On the basis of sequencing data this gene is absent in $E$. coli both upstream and downstream of envM. In addition, Southern hybridization of $E$. coli chromosomal DNA cut with various restriction enzymes gave no signal when the orf 1 DNA was used as a probe in contrast to the control experiment with chromosomal DNA from $S$. typhimurium. Hence, we conclude that this gene is entirely absent from $E$. coli. The position where orf1 appears in the $S$. typhimurium sequence is occupied in $E$. coli by another unusual structural feature. It is a 43-nt-long segment that we designate 'box C'. Southern hybridization experiments using a 43-nt-long synthetic oligonucleotide representing box $\mathrm{C}$ as a probe showed signals with at least five restriction endonuclease fragments from the $E$. coli chromosome. No signal was observed in a similar experiment with $S$. typhimurium DNA, where this sequence motif is probably absent. In $E$. coli, this 


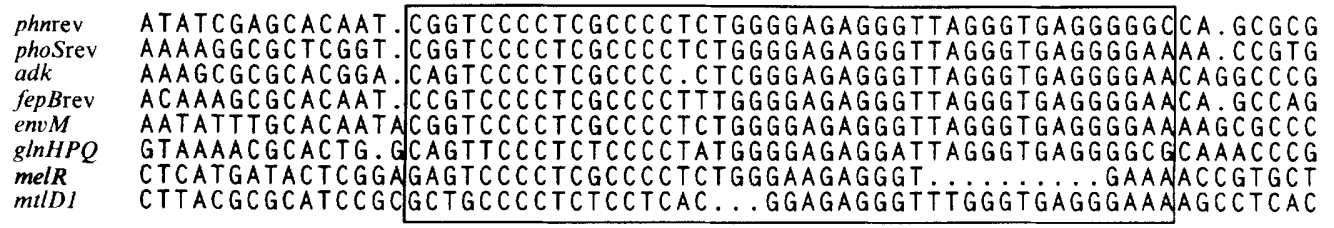

Fig. 3. Multiple sequence alignment of the 43-nt-long box C within the phn (Makino et al., 1991) and phoS (Surin et al., 1985) operons, behind the adk gene (Brune et al., 1985), in front of the $f e p B$ (Elkins \& Earhart 1989) and the envM genes, in the $g \ln H P Q$ operon (Nohno et al., 1986) and preceding the melR (Webster et al., 1987) and the $m t l D I$ genes (GenBank accession number X51359). The appearance of box $\mathrm{C}$ in the direction opposite to the transcriptional orientation in $p h n$, phoS and fepB is indicated as 'rev' following the gene designation.

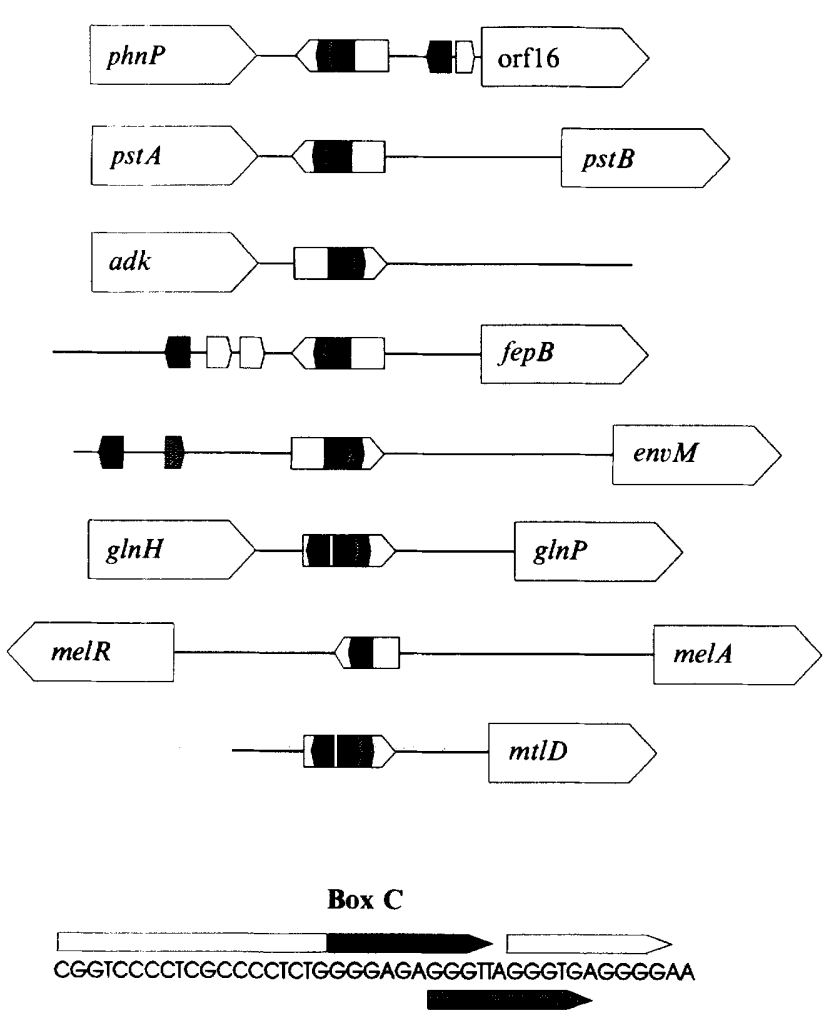

Fig. 4. Location of box $\mathrm{C}$ within the operons and genes listed in Fig. 3. Adjacent genes are indicated according to the transcription direction by arrowheads and the names of the genes. Box $\mathrm{C}$ is shown as a smaller arrowhead. At the bottom the graphical representation of box $\mathrm{C}$ is related to sequence details. The open, shaded and filled bars denote those specific sequence motifs which appear within box $\mathrm{C}$ and outside of it. The arrowhead of box $\mathrm{C}$ in the graphical representation designates the orientation of the sequence as it occurs upstream of envM.

sequence or a slightly modified version thereof appears in the intercistronic region of various operons in both possible orientations. Partial sequences typical for box $\mathrm{C}$ sometimes appear detached from the central region. An example is given in the sequence bordering envM. Here, two such sequence motifs occur upstream of box $C$. They are appropriately marked in Fig. 2 . The sequence of box $\mathrm{C}$ seems to be highly conserved as the multiple sequence alignment in Fig. 3 shows. The arrangement of box $\mathrm{C}$ in various operons is shown in Fig. 4. This sequence and its occurrence in the $f e p B, a d k$, and pst operons of the $E$. coli chromosome was also observed by Elkins \& Earhart (1989). Its function is unknown. However, a possible folding of the transcribed RNA into a hairpin, which this sequence permits, could influence either transcription of the downstream gene(s) or the stability of the entire mRNA.

\section{Cloning and sequencing the diazaborine-resistant envM allele}

Chromosomal DNA was prepared from the diazaborineresistant mutant $E$. coli D10-1. The DNA was digested with $B a m \mathrm{HI} / E c o$ RI and the fragment mixture ligated into appropriately cleaved pUC118 DNA. After transformation, colonies were screened by hybridization with the DNA from pFT405, a recombinant plasmid containing the envM gene from $S$. typhimurium (Turnowsky et al., 1989). The DNA from positive colonies was prepared in the single-stranded form and sequenced. At position 680 , a G to A transition was observed that caused a Gly for Ser exchange in the amino acid sequence (Fig. 2). In the diazaborine-resistant $S$. typhimurium mutant, the equivalent codon was altered by the same type of transition in comparison to the wild-type gene (Turnowsky et al., 1989). We therefore conclude that the glycine at position 93 of the amino acid chain is important for binding the drug to the protein. Preliminary binding studies with the labelled compound using the equilibrium dialysis technique confirm this proposition (unpublished).

\section{Cloning and sequencing the envM-ts allele}

Chromosomal DNA was prepared from E. coli JP1111 (Egan \& Russell, 1973), digested with BamHI-EcoRI and ligated into pBR322. Transformants were screened by the colony hybridization technique using the $1.6 \mathrm{~kb}-$ 
act 3

pketgran

fixrrm

nodgrm

ap $27 \mathrm{~m}$

dindiol

dienocoara

envmec

ohsterhu
1 MATQDSE.. VALVTGATS. . GIGLEIARRIGEEGLRFTV . CARGEEGLRTTLKELREAGV

1 MATDAP EAPVALVTGSSS. . GI GQTVAQRLAA GYRVVVNSARSVEDGEKTAAALP DAI Y

29 ARVDRGEPKVMLITGASR. . GIGHATAKLFSEAGHRII SCARQP FDGERCPKEAGNDDHF

1 ..MF EITGRKALVTGASG . A I GGAIARVIHAQGAIV. . . . GIHGTQMRNWRHWQISI

1 .MKLNFSGIRALVTGAGK. . GIGRDTVKALHASGAKVVAVTRTNSDLVSIAKECPGIEPV

34 ... MRIRGEAVLITGGAS. . GLGRALVDRFVAEAKVAVL . . . . . DKSAERIAELETDL

53 LP PNAFOGRVAFITGGGT. . GLGKAMTTFRSSIGAQCVIASRN . . IDVIKATAE ITSKT

1 . MIGFISGKRILVTGVASKISIAYGIAOAMAREGAELAFTYQ . . NOKLKGRVEETAAQI

1 .....ARTVVLITGCSS. . GIGLHLAVRIASDPSOSFKVYATLRDIKTQGRLWEAARAL act 3

pketgran

fixxrm

nodgrm

ap $27 \mathrm{~m}$

dihdiol

dienocoara

envmec

ohsterhu

act 3

pketgran

fixrrm

nodgrm

ap $27 \mathrm{~m}$

dihdiol

dienocoara

envmec

ohsterhu

act 3

pketgran

fixrrm

nodgrm

ap $27 \mathrm{~m}$

dihdiol

dienocoara

envmec

ohsterhu

act 3

pketgran

fixr rm

nodgrm

ap $27 \mathrm{~m}$

dihdiol

dienocoara

envmec

ohsterhu
56 EAD. . GRTCDVRSVP IEAIVAAVVVERY . GPVDVIVNNAGRP GGGATAEIA . . . D . . . DL

$59 \mathrm{~V}$...... . RADV SE DADARRLVDTAVEHY. GRLDVIVNNAGRTRAI P HADIA . . AATPEV

87 QVDLGDHRMLR RAITEVTKKRIAGA..... PIHALVNNAGVS PKTPTGDRMTSITTSTDT

51 WTGSSCSRLIWP IETKSRRLVRERKPTI. KASTSWSTNAGITKDGLFLHMADP . . . . . D

58 CVDLGDWDATEKAIGGI. . . . . . . . . GPVDLIVNNALIVIMQRPLBV . . . . .TKEA

82 GDNVIGTVGDVRSIEDOKOAASRCVART. GRIDTI PNAGI . TDYSTAIVDIPEASIDAA

109 GNRVYAIRCDVRDP DMVHATVIEIIKVA. GHPDVVINNAAGNF ISP SERI . . . . SPRG

56 GSDIV. LQCDVAEDASIDTMFAEI GKVM. PKIDEFVHSIGFAPGDQ. IDGDYVNAVTREG

53 ACP P GSL ETLQLDVRDSKSVVAAARERVTEGRVDVIVCNAGIGILGPLEALG . . . . . EDA<smiles>[CH]1CC2CCC1C2</smiles>

107 MIDVVETNLTGVFRVTROVLKAGGMLERGTGRIVNIASTGGKOG . VVHAAPYSASKHGVV 109 WRE I IGLNV I GTWQTTVAAM. . P HLARSGNGSVVNVSSIAGSRP . AGSSI P YAVSEGGHR

141 WMRVF HLNLVAPIIIAQGLFDE. . IRAASGSIVNVTSIAGSRVHP FAGSAYATSKAALA

104 WDIVLEVNL TAME RLTREI . TQQMIRRRNGRIINVTSVAGAIGN RQT . NYCAS KAGMI

100 FDRSF SVNL RSVEQVS. QMVARDMINRGVP GSIVNVSSMVARVTF . NIITYSSTKGAMT

140 EDEVT HINVRGY IHAVKAL PA. . . IVIASRGNVITT I SNAGTYPNGGGPI . YTAAKOAIV

162 WRTITDIVLNGTAYVTIEI . . GKQLIKAQKGVAILAITTIYAESGSGFVMP SS SAKSGVE

113 FKIAHD ISSYSEVAMAKACRS. . . . MLNPGSALLTLSYLGAERA IPNYNVMGLAKASLE

107 VASVIDVNVVGTVRMLQAFI . . P DMRRRGSGRVLVTGSVGGLMGIPFNDV . YCASKFALE

166 GFTKALGLELARTG ITVNAVCPGFVETPMAASVREHYSD IWEVSTEEAFDRITARVP IGR 166 AQTRILANTVG. PAVRVNAVAPGI IETP . . . . NTQNSDFFAPIAE . . . HVRQTTPIRR 198 SITRELAHDYAPHG IRVNA I AP GEIRT . . . . . . . . DMLSPDAF . . ARVVASIPIRR

161 GTSKSWRRR. STRNITVNCVAPGTIE......... SAMTDKLNERQKGKIMVAIP IHR

158 MLTKAMAMELGPHKI RVNSVNPTVVITDMGKKV. . . . . . SADPEFARKLKERHPLRK

195 GLVRELATELAPY VRVNGVGPGGMUSDMRGPSSIGMGSK . AISTVPLADMLKSVIP IGR

220 AMNKSIAAEWGRYGMRENIIQPGP IKTKGAESRID. . . . . . PTGKFEKDMIERIPCGR

168 ANVRYMANAMGP EGVRVNAI AAGPIRTLAASGIKDF . . . . . . . RKMLAHCEAVTPIRR

164 GICESLAVILIPFGVHLSIIECGPVHTAFMEKVIGSPEEVIDRTDTHTEHRYYQYIAHSK

226 YVRP SEVAEMVAYLIG . PGAAAVTAQALNVCGGLGNY . . . . . . . .

216 TGRP EDVAEAVIGLV. . . RATYTTGQVILVDGGAHII . . . . . . . . . . .

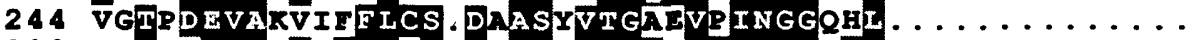

209 MGTGTEVASAVAYLAS. DHAAYVTGQTI HVNGGMAMI . . . . . . . . . .

209 FAEVEDVVNSIITLIS.DRSASTSGGGILVDAGYIAG . . . . . . . . .

253 MP EVE EYTGAYVFEATRGDAAPAS GALVAYD G GIGVRGTISGAG .......

272 LGTVE EIANLATFLCS. DYA SWIMJGAVIREDGGEEVEISGEFNSIKK. . .

219 TVTIEDVGNSAAFLCS.DISAGISGEVVHVDGGTS IAAMNEIELK . . . .

224 QVFREAAQNPEEVAEVTITALRAPEPTLRYFTTERFIPLLRMRLDDPSGS

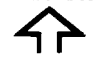

Fig. 5. Sequence homology between some members of the short-chain alcohol dehydrogenase family and the EnvM protein. Amino acids identical to those in EnvM and conservative substitutions are shaded black and grey, respectively. The putative nucleotidebinding region is marked with a bar above the sequences. The amino acid residues in positions 93 and 241 , which lead to the diazaborine-resistance and the ts-phenotype, respectively, are marked with open arrowheads below the sequences. Abbreviations used are: act3, actIII gene from Streptomyces coelicolor (Hallam et al., 1988); pketgran, polyketide dehydrogenase (orf6) from Streptomyces violaceoruber (Sherman et al., 1989); fixrrm, fixR gene from Bradyrhizobium japonicum (Thöny et al., 1987); nodgrm, nodG gene from Rhizobium meliloti (Debelle \& Sharma, 1986); ap27m, adipocyte protein 27 (Navre \& Ringold, 1988); dihdiol, dihydrodiol dehydrogenase (bphB gene) from Pseudomonas pseudoalcaligenes (Furukawa et al., 1987); dienocoara, 2,4-dienoyl-CoA reductase from rat liver (Hirose et al., 1990); envmec, envM gene from E. coli (this work); ohsterhu, human placental 17 $\beta$-hydroxysteroid dehydrogenase (Peltoketo et al., 1988). 
long PstI fragment from pHAP1 as a probe. DNA was prepared from a positive transformant, the insert subcloned into sequencing vectors and sequenced as described above. A single point mutation was observed, i.e. a $\mathrm{C}$ to $\mathrm{T}$ transition at position 1125 (Fig. 2). This mutation causes a Ser for Phe exchange at amino acid 241 of the amino acid sequence. The electrophoretic mobility of the EnvM-ts protein in partially purified samples isolated from overexpressing strains was consistently faster than that of the wild-type protein. The apparent molecular mass of the ts-protein was approximately $2000 \mathrm{Da}$ smaller. The mutation could generate a proteolytic cleavage site which would lead to a protein lacking the $21 \mathrm{C}$-terminal amino acids. This size reduction would explain the observed change in electrophoretic mobility. Alternatively, the mutation could directly influence the electrophoretic mobility of the protein.

Overproduction of the ts-protein in the ts-mutant $E$. coli JP1111 partially restored the growth defect at the nonpermissive temperature (data not shown). The exposure of the ts-protein at the nonpermissive temperature probably does not result in a quantitative destruction of its activity. Hence, the overproduction of this protein yields enough residual activity in order to sustain growth at the nonpermissive temperature.

\section{Comparison of amino acid sequences}

Multiple alignment of the amino acid sequence of EnvM with sequences from databases showed significant homologies of EnvM with the so-called short-chain alcohol dehydrogenases (Jörnvall et al., 1984, Persson et al., 1991, Baker 1990a, b), an example being $27 \%$ identity and $46 \%$ similarity, respectively, between EnvM and the dienoyl-CoA reductase from rat liver. The alignment is shown in Fig. 5. The nucleotide-binding domain of this family of proteins is assumed to be located in the N-terminal part of the sequence (Baker 1990 $b$; Navre \& Ringold, 1988; Jörnvall et al., 1984). The glycine residue at position 93 of the EnvM protein, whose exchange for serine results in diazaborine resistance, appears to be highly conserved. The serine at position 241 , whose exchange for phenylalanine leads to a ts-phenotype, is at a location where hydrophilic amino acids, i.e. threonine or serine, appear. The introduction of an aromatic amino acid at this position obviously has a dramatic effect on the structure of the protein.

The relationship of EnvM, a protein which plays a crucial role in lipid biosynthesis, with this class of dehydrogenases is surprising, because it shows that knowledge about metabolic pathways of lipids is still incomplete. Presently, we are testing whether addition of purified EnvM to a lipid extract in the presence or absence of $\mathrm{NAD}^{+}$alters the lipid composition. The identification of a substrate-product relationship would allow an assessment of the physiological function of this protein.

The expert help of Petra Wallner and Astrid Stecher is gratefully acknowledged. We are grateful to Yuji Kohara for providing the recombinant lambda phage and to Barbara Bachmann for supplying strains. We thank Günther Koraimann for synthesizing oligonucleotides and for his help with the computer work and Heinrich Aschauer for determining the $\mathrm{N}$-terminal amino acid sequence. This work was supported by the Fonds zur Förderung der wissenschaftlichen Forschung, grant no. P7939.

\section{References}

Ausubel, F. M., Brent, R., Kingston, R. E., Moore, D. D., Smith, J. A., Seidman, J. G. \& Struhl, K. (1987). Current Protocols in Molecular Biology. New York: John Wiley.

BAKER, M. E. (1990a). A common ancestor for human placental 17 $\beta$ hydroxysteroid dehydrogenase, Streptomyces coelicolor ActIII protein, and Drosophila melanogaster alcohol dehydrogenase. Faseb Journal 4, 222-226.

BAKER, M. E. (1990 b). Sequence similarity between Pseudomonas dihydrodiol dehydrogenase, part of the gene cluster that metabolizes polychlorinated biphenyls, and dehydrogenases involved in metabolism of ribitol and glucitol and synthesis of antibiotics and $17 \beta$ oestradiol, testosterone and corticosterone. Biochemical Journal 267, 839-841.

Brune, M., Schumann, R. \& Wittinghofer, F. (1985). Cloning and sequencing of the adenylate kinase gene (adk) of Escherichia coli. Nucleic Acids Research 13, 7139-7151.

Casabadan, M. J. \& Cohen, S. N. (1980). Analysis of gene control signals by DNA fusion and modification of DNA in Escherichia coli. Journal of Molecular Biology 138, 179-207.

Debelle, F. \& ShaRMA, S. B. (1986). Nucleotide sequence of Rhizobium meliloti RCR2011 genes involved in host specificity of nodulation. Nucleic Acids Research 14, 7453-7472.

DeVereux J. R., Haeberli P. \& Smithies O. (1984). A comprehensive set of sequence analysis programs for the VAX. Nucleic Acids Research 12, 387-395.

EGAN, A. F. \& Russell, R. R. B. (1973). Conditional mutants affecting the cell envelope of E. coli K12. Genetical Research 21, 139-152.

Elkins, M. F. \& Earhart, C. F. (1989). Nucleotide sequence and regulation of the Escherichia coli gene for ferrienterobactin transport protein FepB. Journal of Bacteriology 171, 5443-5451.

Furukawa, K., Arimura, N. \& MiYazaki, T. (1987). Nucleotide sequence of the 2,3-dihydroxybiphenyl dioxygenase gene of Pseudomonas pseudoalcaligenes. Journal of Bacteriology 169, 427-429.

Grassberger, M. A., Turnowsky, F. \& Hildebrand, J. (1984). Preparation and antibacterial activities of the 1,2,3-diazaborine derivatives and analogues. Journal of Medicinal Chemistry 27, 947953.

Hallam, S. E., Malpartida, F. \& Hopwood, D. A. (1988). Nucleotide sequence, transcription and deduced function of a gene involved in polyketide antibiotic synthesis in Streptomyces coelicolor. Gene 74, 305-320.

Hirose, A., KamiJo, K., Osumi, T., Hashimoto, T. \& Mizugaki, M. (1990). cDNA cloning of rat liver 2,4-dienoyl-CoA reductase. Biochimica et Biophysica Acta 1049, 346-349.

HögeNAUER, G. \& WOISETSCHLÄGER, M. (1981). A diazaborine derivative inhibits lipopolysaccharide biosynthesis. Nature, London 293, 662-664.

JÖRNVALL, H., VON BAHR-LiNDSTRÖM, H., JANY, K.-D., UlMER, W. \& FröSCHLE, M. (1984). Extended superfamily of short alcohol-polyolsugar dehydrogenases: structural similarities between glucose and ribitol dehydrogenases. FEBS Letters 165, 190-196. 
Kohara, Y., Akigama, K. \& Isono, K. (1987). The physical map of the whole $E$. coli chromosome. Application of a new strategy for rapid analysis and sorting of a large genomic library. Cell 50, 495508.

Makino, K., Kim, S.-K., Shinagawa, H., Amemura, M. \& Nakata, A. (1991). Molecular analysis of the cryptic and functional phn operons for phosphonate use in Escherichia coli K-12. Journal of Bacteriology 173, 2665-2672.

Melton, D. A., Krieg, P. A., Rebagliati, M. R., Maniatis, T., ZinN, K. \& GREEN, M. R. (1984). Efficient in vitro synthesis of biologically active RNA and RNA hybridization probes from plasmids containing a bacteriophage SP6 promotor. Nucleic Acids Research 12, 7035-7070.

Miller, J. H. (1972). Experiments in Molecular Genetics. Cold Spring Harbor, NY: Cold Spring Harbor Laboratory.

NAVRe, M. \& Ringold, G. M. (1988). A growth factor-repressible gene associated with protein kinase $\mathrm{C}$-mediated inhibition of adipocyte differentiation. Journal of Cell Biology 107, 279-286.

NoHno, T., SAITo, T. \& Hong, J.-S. (1986). Cloning and complete nucleotide sequence of the Escherichia coli glutamine permease operon $(g \ln H P Q)$. Molecular and General Genetics 205, 260269.

Peltoketo, H., IsomaA, V., Mäentausta, O. \& Vihko, R. (1988). Complete amino acid sequence of human placental $17 \beta$-hydroxysteroid dehydrogenase deduced from cDNA. FEBS Letters 239, 73-77.

Persson, B., KrooK, M. \& Jörnvall, H. (1991). Characteristics of short-chain alcohol dehydrogenases and related enzymes. European Journal of Biochemistry 200, 537-543.
Sambrook, J., Fritsch, E. F. \& Maniatis, T. (1989). Molecular Cloning: A Laboratory Manual, 2nd edn. Cold Spring Harbor, NY: Cold Spring Harbor Laboratory.

SANGer, F., Nicklen, S. \& Coulson, A. R. (1977). DNA sequencing with chain terminating inhibitors. Proceedings of the National Academy of Sciences of the United States of America 74, 5463-5464.

Sherman, D. H., Malpartida, F., BibB, M. J., Kieser, H. M., BibB, M. J. \& HopwOOD, D. A. (1989). Structure and deduced function of the granaticin-producing polyketide synthase gene cluster of Streptomyces violaceoruber Tü22. EMBO Journal 8, 2717-2725.

Silhavy, T. J., Berman, M. L. \& Enquist, L. W. (1984). Experiments with Gene Fusions. Cold Spring Harbor, NY: Cold Spring Harbor Laboratory.

Surin, B. P., Rosenberg, H. \& Cox, G. B. (1985). Phosphate-specific transport system of Escherichia coli: nucleotide sequence and genepolypeptide relationships. Journal of Bacteriology 161, 189-198.

ThöNY, B., Fischer, H.-M., ANThamatten, D., Bruderer, T. \& HENNECKE, H. (1987). The symbiotic nitrogen fixation regulatory operon (fixRnifA) of Bradyrhizobium japonicum is expressed aerobically and is subject to a novel nif $A$-independent type of activation. Nucleic Acids Research 15, 8479-8499.

Turnowsky, F., Fuchs, K., Jeschex, C. \& Högenauer, G. (1989). envM genes of Salmonella typhimurium and Escherichia coli. Journal of Bacteriology 171, 6555-6565.

VIEIRA, J. \& MEssing, J. (1987). Production of single-stranded plasmid DNA. Methods in Enzymology 153, 3-11.

Webster, C., Kempsell, K., BoOth, I. \& Busby, S. (1987). Organisation of the regulatory region of the Escherichia coli melibiose operon. Gene 59, 253-263. 